\title{
Juvenile Heat Stress Tolerance in Triticum Durum - Aegilops Tauschii Derived Synthetics: a Way Forward for Wheat Improvement
}

\author{
Amandeep Kaur \\ Punjab Agricultural University \\ Satvir Kaur Grewal \\ Punjab Agricultural University \\ Sarabjit Kaur \\ Punjab Agricultural University \\ Achla Sharma \\ Punjab Agricultural University \\ Puja Srivastava \\ Punjab Agricultural University \\ Monika Garg \\ National Agri-Food Biotechnology Institute: National Agri-Food Biotechnology Institute \\ Shabir Hussain Wani \\ Sher-e-Kashmir University of Agricultural Sciences and Technology of Jammu \\ Parveen Chhuneja \\ Punjab Agricultural University \\ Kuldeep Singh \\ International Crops Research Institute for the Semi-Arid Tropics \\ Satinder Kaur ( $\sim$ satinder.biotech@pau.edu ) \\ Punjab Agricultural University https://orcid.org/0000-0003-3704-3074
}

\section{Research Article}

Keywords: Synthetic wheat, ROS, MDA, seedling, heat stress tolerance, amylase

Posted Date: February 28th, 2022

DOI: https://doi.org/10.21203/rs.3.rs-1332518/v1

License: (c) (i) This work is licensed under a Creative Commons Attribution 4.0 International License. Read Full License 


\section{Abstract}

Background: Exponentially increasing population and everchanging climatic conditions are two major concerns for the global food security. Early sowing in second fortnight of October is an emerging trend with farmers in Indo Gangetic Plains to avoid the yield losses from terminal heat stress. This also benefits the use of residual soil moisture of rice crop, conserving about one irrigation. But most of the available wheat cultivars are not well adapted to early season sowing.

Methods and Results: Two In-house developed SHWs, syn14128 and syn14170, were screened for juvenile heat stress. Seedling length, biochemical parameters and expression of amylase gene immediately after heat shock (HS) of $45^{\circ} \mathrm{C}$ for $12 \mathrm{hr}$ and $20 \mathrm{hr}$ and $24 \mathrm{hr}$ indicated a significantly lower MDA, $\mathrm{H}_{2} \mathrm{O}_{2}$ and higher free radical scavenging activities. Syn14170 reported higher total soluble sugar (TSS) under both $\mathrm{HS}$ periods, while syn14128 had a sustainable TSS content and amylase activity under HS as well as the recovery period.

Conclusions: Both the SHWs had a lower oxidative damage along with high free radical scavenging under heat stress. The higher expression of amy4 along with sustainable TSS after heat stress in syn14128, indicated it as a potential source of juvenile heat stress tolerance. Variable response of SHWs to different biochemical parameters under heat stress opens the future perspectives to explore the enzymatic pathways underlying these responses.

\section{Introduction}

Wheat is major crop feeding about $35 \%$ of the world population as a staple food providing major calories and proteins [1]. Starting from the green revolution tremendous efforts were made in improving wheat yields in India raising yields from 6.5Mt in 1960 to 104Mt in 2020-21 [2]. This jump in yield is the outcome of consensus efforts of improving yield parameters and counteracting biotic and abiotic stresses. Gangetic plains of South Asia are the major producer of wheat are expected to face a serious threat to sustainable wheat production by 2050 due to climate change, decline in the ground water table, and fading soil fertility $[3,4]$. Being a cool-season crop, wheat requires an optimal temperature between 12 to $25^{\circ} \mathrm{C}$ for germination and seedling establishment, while the optimum temperature range for anthesis and grain filling is between 12 and $22^{\circ} \mathrm{C}$ [5]. Elevated temperature is one of the most critical factors limiting crop growth and productivity around the globe leading to a dramatic reduction in the economic yield of agricultural produce [6, 7]. The global temperature is expected to rise by 1.5 to $4.5^{\circ} \mathrm{C}$ until the end of the current century, and with each $1^{\circ} \mathrm{C}$ rise in temperature, 3 to $17 \%$ reduction in the wheat yield is predicted in the wheat growing regions of South Asia especially India and Pakistan [4].

The temperatures in the second week of November are optimum for the good germination, seedling establishment, and tillering of wheat in these regions but often exposes the crop to terminal heat stress reducing overall yield gains. Preponing this sowing window to the second fortnight of October will lead to early maturity in the month of March, quite earlier to the onset of heat stress on developing seed. Early sowing also helps the farmers to utilize the residual moisture left by rice crop, helping to conserve water reducing at least one irrigation, and also promoting zero tillage practices $[8,9]$. Wheat-rice crops are grown sequentially in double cropping pattern in the Indo Gangetic plains and this rotation builds the framework of the economic backbone of this region. But this rotation is a major concern to environmental sustainability as the severely affects the underground water table.

With all these advantages associated with early sowing, there is a need to shift focus on wheat lines which perform better when sown in the month of October. Higher temperatures during the second fortnight of October matter of concern as it affects germination efficiency, seedling establishment, and vigor of the wheat plant. A high-temperature $\left(>27^{\circ} \mathrm{C}\right)$ stress on wheat at the seed germination stage causes embryo death and decline seedling establishment rate [10] and reduces root/shoot length and dry mass, and membrane stability index [11]. Exposure to the elevated temperatures initiates signals to adjust plant metabolism, and membrane fluidity accordingly and also leads to the production of $\mathrm{H}_{2} \mathrm{O}_{2}$ a secondary metabolic that involves in signaling under stress; reactive oxygen species (ROS) causing oxidative damage, accumulation of osmolytes like proline in the plant which ultimately leads to death $[6,11,12]$. Heat stress elicits the production and accumulation of RoS and detoxification by antioxidants is very much necessary for protecting the plant from the detrimental effect of heat stress [13]. The major metabolic pathway affected by heat stress during seed germination and seedling establishment is the utilization of stored seed starch into simple sugars [14]. Amylases, a family of endoamylases including $a, \beta$, and glucoamylase, a-amylase, catalyze the hydrolysis of $\alpha-1,4 \mathrm{glycosidic} \mathrm{linkages} \mathrm{of}$ starch, converting it into soluble substrates for other enzymes to attack [15]. Among these, a-amylases are known to play a significant role during the germination and seedling establishment stage and their biosynthesis is influenced by fluctuations in the environmental factors such as water, temperature, and calcium levels $[16,17]$. a-Amylase mRNAs first appear in the embryo between 0.5 day to 1 day, followed by aleurone tissue in 2 days and are increased up to 6 days and are activated by sugar starvation, and repressed by sugar provision [18, 19].

Either to avoid terminal heat stress, crave for more yield, or need to save water, the search ends at the selection of genotypes that can germinate and establish themselves at high temperatures and grow into healthier plants. Till date, scientists have been focusing on the terminal heat stress and so far, no significant efforts have been made to breed wheat for early heat stress tolerance under October sowing. A recent study by Uttam et al. [8] screened wheat varieties and adapted germplasm for early (October) sowing and was able to identify a few genotypes which can perform 
good under juvenile heat stress. But the narrow genetic base of the cultivated wheat will pose a major limiting factor for wheat improvement for juvenile heat stress tolerance. One of the easiest and most effective methods to introduce new genetic diversity and novel alleles in the wheat gene pool is the generation of synthetic hexaploid wheats (SHWs). Triticum durum $(2 \mathrm{n}=4 \mathrm{x}=28 ; \mathrm{AABB})$ and Aegilops tauschii Coss. ( $2 \mathrm{n}=2 \mathrm{x}=14$; DD) derived SHWs are the most common and extensively exploited type of wheat synthetics and have been a good resource for improvement against various quality traits as well as biotic and abiotic stresses [20,21]. However, SHWs have primarily been exploited as a source to introduce the terminal heat stress tolerance in the modern-day wheat cultivars $[22,23]$. The use of SHWs to introduce juvenile stage heat stress tolerance in wheat is still an unexplored area. The present investigation was targeted to explore the juvenile stage heat stress tolerance in SHWs based on their response to oxidative stress and free radical species and activity of a- amylase in SHWs wheat

\section{Material And Methods}

\section{Plant materials and growth conditions}

Two T. durum - Ae. tauschii synthetic wheats (syn14170 and syn14128), one durum wheat (PBW114) used in the generation of synthetics, and two advanced breeding lines (ABLs) were used for the present study. The ABLs used for the study were improved versions of two prevalent wheat cultivars PBW343, and HD2967 having rust resistance genes. The experiment was planted in three parallel sets - set I, II, and III, each in three replications. Seeds of each genotype were surface sterilized with 1\% (v/v) sodium hypochlorite followed by thorough washing with Milli Q water and kept in the dark at $25^{\circ} \mathrm{C}$ for germination for $48 \mathrm{hrs}$. Eight to ten germinated seedlings with uniform radicle length were transplanted per pot containing 2:1:1 soil - FYM - cocopeat. The three sets were kept in Conviron CMP6050 growth chamber at $25^{\circ} \mathrm{C} / 17^{\circ} \mathrm{C}(16 \mathrm{hr}$ light/ $8 \mathrm{hr}$ dark) at $60 \%$ humidity. 4 days after germination (4DAG), set I was maintained at $25^{\circ} \mathrm{C} / 17^{\circ} \mathrm{C}$ and was treated as control (C). Set II was given heat shock (HS) at $45^{\circ} \mathrm{C}$ for $12 \mathrm{hr}$, and set III was given $45^{\circ} \mathrm{C}$ HS for 20hrs, (Fig. 1). Immediately after HS, the set II and set III was again shifted to $25^{\circ} \mathrm{C}$ for $24 \mathrm{hr}$ to recover from HS. All sets were maintained at16hr light/8hr dark period. For recording biochemical parameters, the leaf samples of growing seedlings were collected from the three sets in three replicates. from set I, at 4DAG as control, from set II, immediately after HS of 12hr (12HS) and then after $24 \mathrm{hrs}$ of recovery after $12 \mathrm{hr}$ of HS (24R12HS). In set III, seedlings were collected $20 \mathrm{hr}$ immediately after HS (20HS) and then after $24 \mathrm{hrs}$ of the recovery period after $20 \mathrm{hrs}$ HS (24R2OHS).

For recording length of developing seedling and expression analysis, seedlings were collected from set II, i.e., at 12HS and 24R12HS and from set III at 20HS and 24R20HS, all in three replicates. For comparison with optimum growth environments, seedlings from set I were collected at parallel time interval as of set II and set III as control. Percentage increment in seedling length was calculated in set II and III as compared to seedling length at a similar time interval from set I.

\section{Biochemical Analysis}

\section{Estimation of lipid peroxidation}

The content of malondialdehyde (MDA) was estimated using the method of Heath and Packer [24] with some modifications. The leaf homogenate was prepared $0.1 \%(\mathrm{w} / \mathrm{v}$ ) Trichloroacetic acid (TCA) and absorbance of the MDA-TBA (Thiobarbituric acid) complex of homogenate was measured at $532 \mathrm{~nm}$, and the correction for non-specific absorbance was measured at $600 \mathrm{~nm}$. The concentration of MDA was calculated using the Beer-Lambert law equation with an extinction coefficient of $155 \mathrm{mM}^{-1} \mathrm{~cm}^{-1}$.

\section{Estimation of hydrogen peroxide $\left(\mathrm{H}_{2} \mathrm{O}_{2}\right)$ content}

$\mathrm{H}_{2} \mathrm{O}_{2}$ content was measured spectrophotometrically after reaction with potassium iodide (KI) according to the method of Alexieva et al [25] with slight modification. The absorbance of the reaction mixture consisting of leaf homogenate, 100mM Potassium-phosphate buffer (pH 7.0), and reagent ( $1 \mathrm{M} \mathrm{KI}$ in double-distilled water) was measured at $390 \mathrm{~nm}$. The amount of $\mathrm{H}_{2} \mathrm{O}_{2}$ was determined in $\mu$ moles/g FW using a standard curve prepared with a known concentration of $\mathrm{H}_{2} \mathrm{O}_{2}$.

\section{Preparation of methanol extract}

Leaf samples $(0.05 \mathrm{~g})$ collected from all three sets in three replicates for each treatment, were immediately frozen in liquid nitrogen. The leaf samples were extracted with $80 \%$ methanol, refluxed in a water bath at $70^{\circ} \mathrm{C}$ for 1 hour, followed by filtration with Whatman No. 1 and the final volume was made with $80 \%$ methanol. This extract was stored at $4^{\circ} \mathrm{C}$ temperature and used to assess antioxidant activities and phenolic compounds in the biochemical tests discussed in the next sections.

\section{DPPH (2,2-diphenyl-1-picrylhydrazyl) assay of antioxidant activity}

DPPH assay was performed using a modified version of Blois [26] method. $1 \mathrm{ml}$ of appropriately diluted methanolic extract was mixed with $3 \mathrm{ml}$ of $0.1 \mathrm{mM}$ DPPH in amber-colored test tubes. The reaction mixture without sample extract served as a control. After incubation of $30 \mathrm{~min}$ in the dark at room temperature, the discoloration of DPPH was measured against the reagent blank at $517 \mathrm{~nm}$. 


\section{Estimation of superoxide anion radical scavenging activity}

The superoxide anion $\left(\mathrm{O}_{2}^{-}\right)$radical scavenging activity was measured by spectrophotometric monitoring of the inhibition of pyrogallol autoxidation as described by Marklund and Marklund [27]. The antioxidant activity was expressed in terms of the percentage of inhibition of pyrogallol autoxidation, which was calculated from the absorbance in the presence or absence of pyrogallol and the sample mixture. The reaction mixture containing methanol instead of the sample served as a control.

\section{Estimation of nitric oxide free radical scavenging activity}

Nitric oxide (NO) generated from sodium nitroprusside, and the nitrite molecule was measured by the Griess reaction ( $1 \%$ sulphanilamide, $0.1 \%$ naphthylethylenediamine dichloride (NED), and $2 \%$ phosphoric acid). Aqueous sodium nitroprusside at physiological pH spontaneously generates nitric oxide, which reacts with an oxygen molecule to produce nitrite ions [28]. The nitrite ion production can be estimated by using a freshly prepared Griess reagent. $0.2 \mathrm{ml}$ aqueous sodium nitroprusside and $0.2 \mathrm{M} \mathrm{Na}_{2} \mathrm{HPO}_{4}(\mathrm{pH} 7.8)$ were added to $0.1 \mathrm{ml}$ methanolic extract of leaf samples. The mixture was incubated in the dark for two and a half an hour at room temperature. Finally, $0.25 \mathrm{ml}$ of Griess reagent was added, and absorbance was measured at 540nm against water blank using a UV-Visible spectrophotometer.

\section{Estimation of hydroxyl radical scavenging activity}

The hydroxyl radical scavenging assay is based on the Fenton-type reaction generating hydroxyl radical $\left(\mathrm{OH}^{\circ}\right)$ and was estimated using the method described by Li et al. [29] with slight modifications. The reaction mixture consisted of $1 \mathrm{ml}$ of 1,10 phenanthroline $(0.75 \mathrm{mM}), 1 \mathrm{ml}$ of FeSO $(0.75 \mathrm{mM}), 1.9 \mathrm{ml} 0.2 \mathrm{M}$ sodium phosphate buffer $(\mathrm{pH} 7.4), 0.1 \mathrm{ml}$ of sample extract. $1 \mathrm{ml}$ of $0.02 \%$ hydrogen peroxide was added to initiate the reaction in each sample. The samples were then incubated at $37^{\circ} \mathrm{C}$ for $1 \mathrm{hr}$. The absorbance of the solution was read at $536 \mathrm{~nm}$ against blank to check the scavenging activity. The control was prepared by adding buffer in place of the sample.

\section{Estimation of total phenols}

The content of total phenols (TP) was quantified with Folin's reagent using the method described by Swain and Hillis [30]. By using gallic acid in

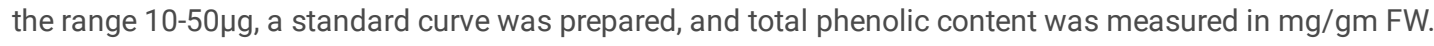

\section{Estimation of total flavanols}

The total flavanol (TF) content was estimated using aluminium chloride colorimetric assay as described by Zhishen et al. [31]. A standard curve of rutin $(40-200 \mu \mathrm{g})$ was also prepared simultaneously, and the content of total flavonoids was calculated from the standard curve.

\section{Estimation of total soluble sugars}

Free sugars were extracted from $0.3 \mathrm{~g}$ of leaf samples collected from the treatment sets in three replications with $15 \mathrm{ml}$ of $80 \%$ ethanol followed by $70 \%$ methanol by keeping the tubes fitted with water condensers in a boiling water bath for 20 mins. Extracts were evaporated at $50^{\circ} \mathrm{C}$ in a flash evaporator under a vacuum, and the final volume was made with distilled water. Total sugars were estimated by using the phenolic sulphuric method of Dubois et al. [32]. The concentration of total sugars (as glucose) was calculated from the glucose standards (10-50 $\mu$ g) which were run simultaneously.

\section{Estimation of alpha-amylases}

The extraction of a-amylase was carried out following the method of Doehlert and Duke [33]. 100mg tissue was extracted in 50mM sodium acetate buffer $(\mathrm{pH} 5.0)$ containing $1 \mathrm{mM} \mathrm{CaCl}_{2}$. The homogenate was aged for $1 \mathrm{hr}$ at room temperature and was centrifuged at $10,000 \times \mathrm{g}$ for $20 \mathrm{mins}$ at $4^{\circ} \mathrm{C}$. The supernatant obtained was used as an enzyme extract and was incubated with $2 \%$ starch in the presence of $50 \mathrm{mM}$ sodium acetate buffer ( $\mathrm{pH} 5.0$ ) containing $1 \mathrm{mM} \mathrm{CaCl}_{2}$ for one hour at $37^{\circ} \mathrm{C}$. The reaction was stopped by the addition of $1 \mathrm{ml}$ alkaline copper tartrate and boiling for $20 \mathrm{mins} .1 \mathrm{ml}$ of arsenomolybdate was added after cooling the tubes followed by $7 \mathrm{ml}$ of $\mathrm{H}_{2} \mathrm{O}$. The content was measured at $510 \mathrm{~nm}$, and the activity was determined by subtracting the concentration of starch left after hydrolysis from the starch present in the substrate blank. Expression analysis of alpha-amylase gene

Gene expression levels of a -amylase gene were estimated in the seedlings under heat stress. The total RNA was isolated from the collected samples using Qiagen RNAEasy® Plant Mini Kit according to the manufacturer's protocol. RNA integrity was electrophoretically verified by the ethidium bromide staining and by $\mathrm{OD}_{260} / \mathrm{OD}_{280} \mathrm{~nm}$ absorption ratio of higher than 1.95. DNA-free total RNA (5mg) from different treatments was used for the first-strand cDNA synthesis following the instruction of the PrimeScript ${ }^{\text {TM }} 1$ st strand cDNA Synthesis Kit (Takara). qPCR was conducted using SYBR Green I Mastermix (Takara) using Roche LightCycler96 Real-Time PCR machine. The housekeeping (Tubulin) gene and aamylase (amy4) gene oligonucleotide primers along with the reaction conditions, were adapted from Kaur [18]. Melting curves were performed at $55^{\circ} \mathrm{C}$ and were analyzed using LightCycler96 software package supplied by Roche. The $\mathrm{C}_{\mathrm{q}}$ (quantification cycle value) value and the relative expression level of amylase and the relative expression level of the housekeeping (Tubulin) were estimated in each sample. Relative fold differences were calculated based on the comparative $\mathrm{C}_{\mathrm{q}}$ method using the Tubulin as the endogenous control. For the relative differences in the 
target gene for each treatment, the $C_{q}$ value for the target gene was normalised to the $C_{q}$ value for Tubulin. The relative fold change in the target gene was calculated for each sample using the equations $2^{-\Delta \Delta C q}$ [34] given below. For the untreated control sample, $\Delta \Delta \mathrm{C}_{\mathrm{q}}$ equals zero, and $2^{0}$ equals one. For the treated samples, $2^{-\Delta \Delta \mathrm{Cq}}$ indicates the fold change in gene expression relative to the control. This method was used to calculate the relative change in gene expression. According to $\Delta \Delta \mathrm{C}_{\mathrm{q}}$ method:

$$
\begin{gathered}
\Delta C_{q}=\Delta C_{q T a r g e t}(\alpha-\text { Amylase) } \\
\Delta \Delta C_{q}=\Delta C_{q \text { Test Sample (stressed) }}-\Delta C_{q \text { Calibrator Sample (control) }}
\end{gathered}
$$

$2^{-\Delta \Delta \mathrm{Cq}}$ represents the fold change in gene expression relative to untreated control.

\section{Statistical analysis}

Data were analysed by one-way ANOVA using "Agricolae" version 1.3-1 Rstudio [35]. Significant differences between treatments were identified at the 0.05 probability level $(P)$ by the Duncan's Multiple Range Test and represented as mean \pm standard error (SE). Percent change in the level of various biochemical parameters was plotted with the help of "ggplot2" version 3.3.2 and "ggpubr" version 0.4.0 packages of RStudio [36, 37].

\section{Results}

The selected genotypes showed seedling length variation at 4DAG with synthetics having minimum length of $8.27 \mathrm{~cm}$ (syn14128) to maximum length of $14.17 \mathrm{~cm}$ in PBW114 (Fig. S1, S2, Table S1, S2). The other SHW, syn14170 reported seedling length similar to that of HD2967 (10.53cm) at 4DAG. The maximum per cent of length increment on 5th DAG and 6th DAG was in syn 14128 (38.71\%, 46.80\%, respectively), while minimum per cent increment in PBW114 (10.55\%, 26.17\%, respectively) (Fig. 2, Table S1, S2). Syn14170, on the other hand, reported a sharp increase of $31.01 \%$ in seedling length at 5th DAG, which was further slowed down to 19.81\% at 6 DAG (Fig. 2). Syn14128 reported a significant better seedling length (56.45\% and $59.68 \%$, respectively) at $12 \mathrm{HS}$ and $20 \mathrm{HS}$ stage as compared to other synthetic, durum and checks. Still, it was not able to maintain this increment rate under the recovery period (15.21\% and 5.05\% decrease compared to control respectively) (Fig. 2 ). However, at 24R12HS and 24R20HS stage, syn14170 reported a better recovery (24.33\% and 25.68\%) than all the other genotypes. Selected ABLs and durum wheat, on the contrary, reported an $8-12 \%$ decrease in the seedling length after HS indicating severe damage to plant cellular machinery.

\section{Heat stress-induced oxidative stress in wheat seedlings}

The increase in MDA content was observed in seedlings after $12 \mathrm{HS}$ and $20 \mathrm{HS}$ as compared to control, followed by a decrease in the MDA content at 24R12HS and 24R20HS (Fig. 3a, Table 1). Under the control conditions, no significant difference in MDA content was observed among selected genotypes. When exposed to $12 \mathrm{HS}, \mathrm{ABLs}$ and durum wheat reported an abrupt increase in MDA content with the maximum increase in PBW114

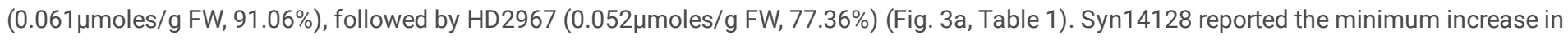
MDA content after $12 \mathrm{HS}$ as well as $20 \mathrm{HS}$ (33.08\% and $68.25 \%$, respectively). At 24R12HS, MDA content decreased by $20-40 \%$ in SHWs while ABLs and durum wheat still reported higher MDA content (30-56\%). However, at 24R20HS only HD2967 had higher MDA content while the rest of the genotypes indicated a decreased MDA level. 
Table 1

Percent change in different parameters as compared to 4 DAG control after different treatments

\begin{tabular}{|c|c|c|c|c|c|c|c|c|c|c|c|c|c|}
\hline Genotype & DAG & Treatment & MDA & $\mathrm{H}_{2} \mathrm{O}_{2}$ & DPPH & $\mathrm{O}_{2}^{-}$ & NO & $\mathrm{OH}^{\circ}$ & TP & TF & TSS & Starch & Amy \\
\hline Syn14128 & 5 & $12 \mathrm{HS}$ & 33.08 & -53.76 & -45.02 & 84.84 & 97.68 & 245.60 & 90.82 & -29.88 & -21.72 & -14.72 & -38.41 \\
\hline Syn14170 & 5 & $12 \mathrm{HS}$ & 33.27 & -71.91 & -44.28 & 53.08 & 139.27 & 158.10 & 97.54 & -37.67 & -53.31 & -12.60 & -49.22 \\
\hline PBW114 & 5 & $12 \mathrm{HS}$ & 91.06 & -54.20 & -63.03 & 137.66 & 97.38 & 367.63 & 221.12 & -13.84 & -10.77 & -9.40 & -26.76 \\
\hline HD2967 & 5 & $12 \mathrm{HS}$ & 77.36 & -84.27 & -72.56 & 82.56 & 59.74 & 482.11 & 164.88 & -28.01 & -40.17 & -21.70 & -56.13 \\
\hline PBW343 & 5 & $12 \mathrm{HS}$ & 69.54 & -80.52 & -82.81 & 18.05 & 72.33 & 283.95 & 272.31 & -32.98 & -10.05 & -23.62 & -50.09 \\
\hline Syn14128 & 6 & 24R12HS & -20.69 & 47.48 & 1.13 & 17.23 & 6.29 & -12.36 & -38.12 & 2.69 & -28.17 & -52.03 & -10.35 \\
\hline Syn14170 & 6 & 24R12HS & -21.24 & 12.97 & 1.49 & 6.61 & 4.95 & -45.53 & -60.99 & -8.25 & -64.48 & -65.33 & -31.28 \\
\hline PBW114 & 6 & 24R12HS & 50.34 & 45.43 & 3.36 & -14.43 & -15.18 & -15.98 & -21.12 & 21.10 & -39.38 & -45.98 & -3.22 \\
\hline HD2967 & 6 & 24R12HS & 32.33 & -13.68 & 2.81 & -18.12 & -27.96 & -1.79 & -9.65 & 6.46 & -63.68 & -53.78 & -22.67 \\
\hline PBW343 & 6 & 24R12HS & 56.19 & 12.41 & 2.98 & -38.33 & -15.85 & -25.04 & -8.08 & 2.02 & -40.42 & -43.38 & -32.26 \\
\hline Syn14128 & 5 & $20 \mathrm{HS}$ & 68.25 & -67.58 & -61.90 & 258.59 & 86.42 & 107.30 & 20.56 & -23.09 & -53.39 & 14.09 & -49.01 \\
\hline Syn14170 & 5 & $20 \mathrm{HS}$ & 73.07 & -71.20 & -56.55 & 122.16 & 71.42 & 256.12 & 49.08 & -27.59 & -48.72 & 4.87 & -59.17 \\
\hline PBW114 & 5 & $20 \mathrm{HS}$ & 105.64 & -75.62 & -66.89 & 170.37 & 41.71 & 227.18 & 165.02 & 4.68 & -3.00 & 2.88 & -45.56 \\
\hline HD2967 & 5 & $20 \mathrm{HS}$ & 106.41 & -65.49 & -70.58 & 188.85 & 21.83 & 293.49 & 127.88 & -29.46 & -7.28 & -20.00 & -69.90 \\
\hline PBW343 & 5 & $20 \mathrm{HS}$ & 150.58 & -82.55 & -74.21 & 249.84 & 23.63 & 89.44 & 207.31 & -32.05 & -33.03 & -22.33 & -66.13 \\
\hline Syn14128 & 6 & 24R20HS & -54.98 & -9.74 & -18.02 & -7.51 & 59.93 & -31.94 & -47.90 & -11.51 & -55.14 & -8.13 & -39.04 \\
\hline Syn14170 & 6 & 24R2OHS & -39.28 & 0.09 & -10.28 & -49.78 & 72.28 & 50.68 & -51.75 & -16.53 & -57.91 & -7.82 & -49.76 \\
\hline PBW114 & 6 & 24R2OHS & -16.80 & -8.80 & -9.75 & -50.76 & 24.16 & 44.19 & 19.47 & 17.95 & -25.62 & -39.03 & -35.75 \\
\hline HD 2967 & 6 & 24R2OHS & 29.32 & -6.01 & -12.07 & 24.77 & 0.89 & 55.79 & 3.75 & -12.19 & -12.37 & -39.63 & -57.83 \\
\hline PBW343 & 6 & 24R2OHS & -3.21 & -17.14 & -14.87 & 6.30 & 20.09 & -18.52 & 32.69 & -28.23 & -40.07 & -30.13 & -63.88 \\
\hline
\end{tabular}

Values represented as percent increase or decrease as compared to control.

The different alphabetical letters in superscript indicate the significant differences with Duncan test at $p$ value 0.05 .

DAG: days after germination, MDA: Malondialdehyde content, $\mathrm{H}_{2} \mathrm{O}_{2}$ : Hydrogen peroxide content, DPPH: percent DPPH content, $\mathrm{O}_{2}^{-}$: superoxide anion free radical scavenging activity, NO: nitric oxide free radical scavenging activity, $\mathrm{OH}^{\circ}$ : hydroxyl anion free radical scavenging activity, TP: total phenol content, TF: total flavanol contents, TSS: total soluble sugar content, Starch: starch content, Amy: amylase activity

$\mathrm{H}_{2} \mathrm{O}_{2}$ level of control set was lower in PBW114 as compared to other genotypes (1.57 $\mu$ moles/g FW, Fig. 3b, Table 1). 12HS and 20HS resulted in a significant decrease in $\mathrm{H}_{2} \mathrm{O}_{2}$ content in the seedlings. After $12 \mathrm{HS}$, syn14128 reported a minimum reduction in the $\mathrm{H}_{2} \mathrm{O}_{2}$ content $(0.98 \mu$ moles/g FW, $53.76 \%$ ) while syn14170 had a $71.92 \%$ decrease in $\mathrm{H}_{2} \mathrm{O}_{2}$ content compared to the control set. However, durum wheat, PBW114, reported a reduction similar to that of syn14128 (54.20\%, Fig. 3b). At 24R12 HS, $\mathrm{H}_{2} \mathrm{O}_{2}$ content increased significantly with no significant difference in syn14128 (47.48\%) and PBW114 (45.43\%). However, at 20HS, HD2967 reported maximum $\mathrm{H}_{2} \mathrm{O}_{2}$ content (0.83 $\mu$ moles/g FW; $82.55 \%$ decrease compared to control) and at 24R20HS syn 14170 was able to recover its $\mathrm{H}_{2} \mathrm{O}_{2}$ content similar to that of control conditions ( $0.09 \%$ ) (Fig. $3 \mathrm{~b}$, Table 1). Both the synthetics had minimum per cent increase in the MDA content along with lower $\mathrm{H}_{2} \mathrm{O}_{2}$ content under $12 \mathrm{HS}, 2 \mathrm{HS}$ as well as $24 \mathrm{R} 12 \mathrm{HS}$ and 24R20HS.

\section{Free radical scavenging activities in wheat seedlings under heat stress}

Free radical scavenging activities were estimated for four different radicals viz., $\mathrm{DPPH}, \mathrm{O}^{2-}, \mathrm{NO}$ and $\mathrm{OH}^{\circ}$. Under the control conditions, all selected lines had statistically similar DPPH scavenging activities ranging from 76-79\% (Fig. 4a, Table 1). While after 12HS, DPPH scavenging activity was reduced with lowest in PBW343 (13.37\%), followed by HD2967 (21.34\%) with a significant reduction (82.81\% and 72.56\%; Table 1) as compared to the control. In synthetics, $\sim 43 \%$ per cent decrease in DPPH scavenging activities was recorded at $12 \mathrm{HS}$ with $\sim 45 \%$ reduction as compared to control. A similar trend was also observed at 20HS, with maximum DPPH reduction in PBW343 (74.21\%) followed by HD2967 (70.58\%), while 
syn14170 had the minimum reduction (56.59\%) in the DPPH scavenging activity followed by syn14128 (61.90\% reduction). However, no significant change in DPPH scavenging was observed at 24R12HS and 24R20HS.

Further, $\mathrm{O}_{2}^{-}$radical scavenging activity was low in the control set and increased significantly after HS (Fig. 4b, Table 1). At 12HS, PBW114 reported a maximum spike in the level of $\mathrm{O}_{2}^{-}$radical scavenging activity ( $137.66 \%$ increase) followed by syn 14128 ( $\left.84.84 \%\right)$. In the case of $20 \mathrm{HS}$,

an abrupt per cent increase in $\mathrm{O}_{2}{ }^{-}$radical scavenging activity was observed in all the genotypes with the maximum growth in the case of PBW343 (249.84\%). However, increased $\mathrm{O}_{2}^{-}$radical scavenging activity was observed in case of two selected synthetics, syn14128 (17.23\%) and syn14170 (6.61\%), in 24R12HS, while other three genotypes indicated a decreased per cent scavenging (Fig. 4b). 24R20HS indicated decreased $\mathrm{O}_{2}{ }^{-}$radical scavenging activity as compared to control in case of synthetics and PBW114, while increased scavenging in case of ABLs.

Syn14170 and syn14128 had significantly lower ( $\mathrm{P}<0.05)(\sim 37 \%)$ NO scavenging activity than elite ( 55\%) and durum (47\%) wheats under control condition which was increased further as the genotypes were exposed to HS (Fig. 4c, Table 1). After 12HS ABLs showed minimum per cent increase (59.74\% and $72.33 \%$, respectively) followed by syn14128 and PBW114 (97\%). Although syn14170 reported maximum per cent increase (139.27\%) after $12 \mathrm{HS}$, syn14128 reported the overall maximum per cent after $20 \mathrm{HS}(86.42 \%)$. ABLs again had the minimum increase $(\sim 22 \%)$ at 20HS. In the case of 24R12HS, NO free radical scavenging activity was decreased (15-27\%) in ABLs and durum wheat while SHWs had $4-6 \%$ higher scavenging as compared to control set. At $24 \mathrm{R} 20 \mathrm{HS}$, an overall percentage increase of NO scavenging was observed in all the genotypes.

$\mathrm{OH}^{\circ}$ radical scavenging had an activity pattern similar to that of $\mathrm{O}_{2}^{-}$scavenging activity, with lower levels of scavenging in control and recovery stages but higher scavenging after HS (Fig. 4d, Table 1). In control, PBW343 showed maximum OH' radical scavenging activity (19.84\%), while HD2967 had the lowest (11.72\%) (Fig. 4d). At 12HS treatment, PBW114 reported maximum levels of OH' scavenging (78.87\%) followed by PBW343 (76.17\%). However, the maximum per cent increase compared to control was reported in HD2967 (482.11\%) followed by PBW114 (367.63\%). Both the SHWs had minimum $\mathrm{OH}^{*}$ scavenging (45.43\% syn $14128,54.36 \%$ syn 14170$)$ and minimum per cent change (245.60\%, $158.10 \%$, respectively) compared to control. At 24R12HS syn14170 indicated a better recovery (45.55\%) than syn14128 (12.36\%). However, a significant difference in the $\mathrm{OH}^{\circ}$ free radical scavenging activity was observed for all the lines after 20HS, and 24R20HS with a maximum per cent change was observed in HD2967 (293.49\%, 55.79\%) followed by syn14170 (256.12\%, 50.68\%). Overall DPPH scavenging was decreased, while $\mathrm{O}_{2}{ }^{-}, \mathrm{OH}^{\circ}$ and $\mathrm{NO}$ scavenging increased under both $12 \mathrm{HS}$ and $20 \mathrm{HS}$. Syn 14170 had a minimum decrease in the DPPH scavenging (44.28\%) along with maximum NO scavenging (139.27\%) for $12 \mathrm{HS}$ set, while a better $\mathrm{OH}^{*}$ radical scavenging $(256.42 \% \%)$ in this synthetic was observed in $20 \mathrm{HS}$ set. On the other hand, syn14128 also reported a minimum decrease in the DPPH scavenging (45.02\%) along with the highest $\mathrm{OH}^{\circ}$ radical scavenging (245.60\%) for $12 \mathrm{HS}$ set. In the case of $20 \mathrm{HS}$ syn 14128 had maximum $\mathrm{O}_{2}{ }^{-}$radical scavenging (258.59\%), maximum $\mathrm{NO}$ scavenging (86.42\%) and average $\mathrm{OH}^{\circ}$ radical scavenging (107.30\%).

\section{Total phenol and total flavanol content in wheat seedlings under heat stress}

In the present study, TP increased under HS condition while the TF decreased when seedlings were exposed to HS. TP content was significantly higher in SHWs in the control set ( 3mg/g FW) as compared to ABLs and durum wheat (1-2mg/g FW) (Fig. 5a, Table 1). An overall increase in the phenolic content was observed at 12HS, but there was no significant variation among selected genotypes ( 6mg/g FW). PBW343 (272.31\%) followed by PBW114 (221.12\%) showed a significantly higher increase in the phenolic content, while SHWs reported the minimum per cent change in total phenol content under 12HS (Table 1). However, syn14170 recovered back quickly from heat damage after 24R12HS with minimum phenolic content $(1.23 \mathrm{mg} / \mathrm{g} \mathrm{FW})$ and maximum per cent decrease in total phenol content (60\%). SHWs reported significantly less phenolic content (3-4mg/g FW) as compared to the elite and durum wheat ( $5 \mathrm{mg} / \mathrm{g} \mathrm{FW})$ in $20 \mathrm{HS}$ treatment. Syn14170 was still observed to recover back quickly after 24R20HS with minimum phenolic content (1.53 mg/g FW, 51.75\%) followed by syn14128 (1.70mg/g FW, $47.90 \%)$ (Fig. 5a). An increase in total phenol levels was observed in ABLs and durum wheat with a maximum per cent increase in PBW343 (32.69\%) followed by PBW114 (19.47\%) in recovery post $20 \mathrm{hr}$ HS.

On the other hand, TF content decreased after HS. In control set, there was no significant difference SHWs and ABLs ( 1mg/g FW), while durum wheat had minimum TF content $(0.82 \mathrm{mg} / \mathrm{g} \mathrm{FW}$ ) (Fig. 5b, Table 1). All the genotypes showed a decrease in flavanol content at $12 \mathrm{HS}$, with maximum percent decrease in syn14170 (0.72mg/g FW, 37.67\%) followed by PBW343 (0.73mg/g FW, 32.98\%) and syn14128 (0.73mg/g FW, $29.88 \%$ ). However, syn 14170 reported $8.25 \%$ decrease in the TF content at 24R12HS, and in all the other genotypes $2-21 \%$ increase in TF content was recorded as compared to control set. Durum wheat, on the other hand, reported an increase in the TF content (4.68\%) for $20 \mathrm{HS}$ treatment, while ABLs and SHWs reported a $23-32 \%$ decline in the levels of flavanol content. A similar trend was observed when these seedlings were given a recovery period of 24 hours.

\section{Effect of heat stress on total soluble sugars and total starch}

In the control set, total soluble sugar (TSS) was highest for syn14170 (21.90mg/g FW) followed by syn14128 (19.78mg/g FW) (Fig. 6a, Table 1). However, at12HS, a decrease in TSS was observed for all the genotypes with a maximum per cent decrease in syn 14170 (53.31\%) followed by 
HD2967 (40.17\%). At 24R12HS treatment, syn14128 reported the highest recovery potential with only $28 \%$ decline in the amount of available sugars, while syn 14170 reported the minimum recovery with $64.48 \%$ decline in TSS. Further, TSS content was decreased by $~ 50 \%$ in the case of SHWs for $20 \mathrm{HS}$ and $24 \mathrm{R} 2 \mathrm{OHS}$.

Selected wheat genotypes did not show a significant difference in the levels of starch content in the control set (Fig. 6b, Table 1). However, at $12 \mathrm{HS}$, minimum starch content was observed in case of syn14128 (9.26mg/g FW) followed by syn14170 (9.87mg/g FW) which was further decreased $(52.03 \%$ and $65.33 \%$, respectively) when at 24R12HS, indicating a better utilisation of starch under HS. At $20 \mathrm{HS}$ and $24 \mathrm{R} 20 \mathrm{HS}$, ABLs reported a decline in starch content ( 21\%) while SHWs and durum wheat reported an increased starch availability, indicating a decreased starch metabolism in these genotypes.

\section{Amylase activity and gene expression of a-Amylase under heat stress}

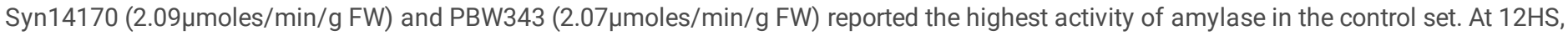
reduced activity of amylase was observed in all the genotypes, but the reduction was more significant in HD2967 (56.13\%) followed by PBW343 (50.09\%) and syn14170 (49.22\%) (Fig. 6c, Table 1). Amylase activity was least affected in PBW114 (1.25 $\mu$ moles/min/g FW, 26.76\% reduction)

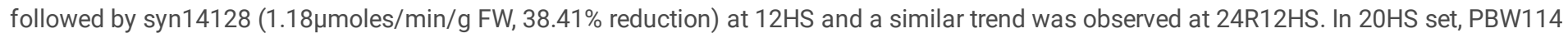
$(0.93 \mu \mathrm{moles} / \mathrm{min} / \mathrm{g} \mathrm{FW})$ again showed minimum reduction (45.56\%) in amylase activity, followed by syn14128 $(0.98 \mu \mathrm{moles} / \mathrm{min} / \mathrm{g} \mathrm{FW}, 49.01 \%$ reduction) and a similar trend was observed for $24 \mathrm{R} 20 \mathrm{HS}$.

In real-time PCR expression profiling of a-amylase targeting amy4 gene (Fig. 6d). a general trend of downregulation due to HS was observed in all the selected wheat lines. However, syn14128 reported significant minimum down-regulation in amy4 activity than the other selected lines at both $12 \mathrm{HS}$ as well as 20HS. Further, amy4 expression in syn14128 also recovered back quickly to control level for 24R12HS as well as $24 \mathrm{R} 20 \mathrm{HS}$ (Fig. 6d). Syn14170, however, has low expression than durum as well as ABL checks.

\section{Discussion}

Practise of early planting in wheat after rice is a trend adopted by Indian farmers, avoid terminal heat stress, to practise zero tillage and use the residual moisture left by rice crop saving both time and energy. Early planting coincides with higher temperature which effect the seed germination, establishment, growth and yield. There is need to expand the heat stress resistance both ways, exploring wheat varieties which could endure HS during the germination and seedling establishment stage along with work on terminal heat stress [38]. Being a newer thought of work, significantly fewer studies have targeted the juvenile stage heat stress. Potential of SHWs for juvenile stage heat stress tolerance is a significantly less explored area and the present study targets two SHW lines, already evaluated for terminal heat stress tolerance, for their potential use in the early/seedling stage heat stress tolerance. The seedlings from the selected wheat genotypes were managed in three different sets as control (set I, at $25^{\circ} \mathrm{C}$ ), $12 \mathrm{HS}$ (set II) and $20 \mathrm{HS}$ (set III) at $45^{\circ} \mathrm{C}$ followed by a $24 \mathrm{hr}$ - recovery period at $25^{\circ} \mathrm{C} \mathrm{(Fig.} 1$ ). Oxidative stress, free radical scavenging activities, total phenol and flavanols along with the starch metabolising enzyme (amylase) were estimated for the selected lines to understand the level of seedling stage heat stress tolerance.

Malondialdehyde (MDA) levels after exposure to stress can be used as an indicator of cellular membrane damage as MDA causes lipid peroxidation of heat stress damaged cell membranes under due to higher lipoxygenase [39]. Heat stress generally increases the MDA content in all the organs of the wheat plant, tolerant genotypes of wheat showed lower lipid peroxidation level than the susceptible ones [40, 41]. The two synthetics used in the present study reported the minimum increase in the MDA levels under two levels of HS and at recovery after HS as compared to ABLs and PBW114. This indicated that the lower membrane damage occurred in these genotypes under HS and their ability to recover minimum damage of membrane integrity after the stress is over. $\mathrm{H}_{2} \mathrm{O}_{2}$ is recognised as an integral component of cell signalling cascades [42].

Along with $\mathrm{MDA}, \mathrm{H}_{2} \mathrm{O}_{2}$ is a strong oxidant and a second messenger in biotic and abiotic stresses [43]. Syn14128 and syn14170 had lower $\mathrm{H}_{2} \mathrm{O}_{2}$ content after $12 \mathrm{HS}$ and $20 \mathrm{HS}$ and better recovery than ABLs and durum wheat, indicating lower oxidative damage in synthetics. Thus on exposing to $\mathrm{HS}$, the decreased $\mathrm{H}_{2} \mathrm{O}_{2}$ content might have initiated its action as a signalling molecule, triggering the tolerance responses in the seedlings of two synthetics used in the present study [44]. PBW343 and $\mathrm{HD} 2967$ with higher $\mathrm{H}_{2} \mathrm{O}_{2}$ content under HS and were not able to recover quickly from the heat damage, suggesting a toxic role of $\mathrm{H}_{2} \mathrm{O}_{2}$ [42].

In cellular redox homeostasis, there is the overproduction of ROS that overwhelms the detoxification system of the plant and make the plant vulnerable. Regular scavenging of these toxic species under stress helps the plants to thrive under adverse conditions. DPPH free radical scavenging activity decreased significantly under heat stress indicating a higher expression of ascorbate peroxidase in the selected wheat lines. Higher levels of DPPH activities have already been correlated with higher levels of ascorbate peroxidase in D-genome donor of wheat, Ae. tauschii by Hairat and Khurana [45]. These higher levels of DPPH and decreased $\mathrm{H}_{2} \mathrm{O}_{2}$ content has also been associated with salinity tolerance and 
drought tolerance $[12,46]$. The production of ROS, mediated by alternate $\mathrm{O}_{2}{ }^{-}$reduction and subsequent oxidative damage in heat-stressed plants, has been reported by several researchers $[13,47]$. Savicka [48] also reported an increased $\mathrm{O}_{2}{ }^{-}$scavenging post $24 \mathrm{hr}$ heat stress in 4 day old and

7-day old seedlings. $\mathrm{OH}^{\bullet}$ is the most reactive free radical and can damage different cellular components by lipid peroxidation, protein damage and membrane destruction. Also, there is no known enzymatic system to scavenge it, making it the most toxic ROS [6, 11, 12]. In addition to the generation of ROS, several reactive nitrogen species (RNS) are also formed in the plants under heat stress. Increased NO scavenging under heat stress in the present study indicated a role of this molecule in the stress tolerance, as per the earlier studies $[6,28]$.

Phenolic compounds are an essential class of secondary metabolites, produced under optimal and suboptimal conditions in plants playing critical roles in developmental processes like cell division, photosynthetic activity. Under temperature stress, plants synthesise more phenols and flavanols to protect the plant cells [49]. The lower increment in the levels of phenols in the selected SHW genotypes under HS suggested that these may be supporting the other biochemical parameters to maintain cell integrity during the heat stress instead of directly causing any impact. Lower, DPPH content has also been reported associated with the high phenolic and flavonoid contents under heat stress in wheat [50].

Heat stress during seed germination and seedling growth affect the activity of carbohydrate metabolising enzymes like amylase. As a seed gets suitable conditions for germination, all the enzymes and other proteins leave their dormant phase and start hydrolysing the starch to soluble sugars. Up to 7 days during seed germination and seedling growth, plant uses the energy from its stored reserves, endosperm. Due to higher temperature, the activity of these proteins was impaired lead to lower availability of soluble sugars. In the present study, a continuous increase in the seedling length was observed from 4th to 6th DAG (Table S1). In the set I (Control), syn14128 indicated minimum seedling length on 4th DAG $(8.27 \mathrm{~cm})$ that might have caused by initial slow metabolism of starch in this genotype which showed an abrupt increase of length on 5 th DAG (138\%) and 6th DAG (146\%). A similar trend was observed at 12HS and 20HS treatment, suggesting the involvement of the starch metabolising enzyme, which can work even under HS conditions. To further understand the metabolism and utilisation of stored starch, total soluble sugar content, total starch and total amylase activity and gene expression of amy4 were estimated in selected lines (Fig. 6). Higher TSS under heat stress indicated the potential of amylase enzyme to metabolise endosperm starch. Syn 14170 and syn14128 suggested a lower starch content along with higher TSS and higher amylase activity under both $12 \mathrm{HS}$ and $20 \mathrm{HS}$ set indicating a stable and functioning amylase enzyme causing degradation of starch and providing the sufficient energy to seedlings for survival even under heat stress conditions [16, 17].

Further, the minimum per cent decrease in amylase activity after HS in case of syn14128 suggested the capacity of amylase to recover quickly from the heat shock. In contrast, amylase activity in syn14170 reported a decrease similar to that of ABL, PBW343 in 12HS, 24R12HS, 20HS and 24R20HS indicating higher damage and lower recovery of starch metabolism system in this SHW. Syn14170 had high TSS under both $12 \mathrm{HS}$ and $20 \mathrm{HS}$ and while syn14128 had less reduction in TSS in 12HS, nominating both of these synthetics as promising candidates for juvenile stage heat stress tolerance.

The germinating wheat seed requires a constant supply of sugars, and amylases are the primary set of enzymes involved in this process. Amylases can act in two different forms and are categorised as endoamylases and exoamylases. Endoamylases, such as a-amylase can cleave a,1-4 glycosidic bonds present in the inner part of the amylose or amylopectin chain. a- amylase constitutes the significant portion and is more sensitive to heat as compared to $\beta$-amylase. To check the effect of heat stress on the utilisation of starch in wheat seedlings, a-amylase (Amy4) gene expression was quantified using quantitative real-time PCR. Amy4 gene has already characterised for seedling stage heat stress in wheat genotypes by Kaur [18]. Syn14128 followed by PBW114 were showing less reduction in total amylase activity in both $12 \mathrm{HS}$ and $20 \mathrm{HS}$ sets as well as under 24R12HS and 24R20HS set as confirmed by expression analysis using quantitative real-time PCR for the a-amylase gene. It suggested that better amylase activity in syn14128 might be a combined effect of PBW114 and Ae. tauschii parent and lower amylase expression and activity in syn14170 might be a trait derived solely from either one of the parents.

The two synthetics targeted as the potential candidates for juvenile stage heat stress tolerance in the present study had lower MDA content, lower $\mathrm{H}_{2} \mathrm{O}_{2}$ content along with better free radical scavenging activities under $12 \mathrm{HS}, 20 \mathrm{HS}$ as well as 24R12HS and 24R20HS indicating less membrane damage and lesser injury to the cellular machinery and a better ability to recover after facing short periods of high temperature. This suggested that these synthetics were better able to mitigate the oxidative stress caused by heat shock as compared to the durum wheat as well as the selected ABLs. This improved capacity of synthetics to endure heat stress is expected to be a probable trait inherited by synthetics from the Dgenome donor of the modern wheat, Ae. tauschii. Further, better total amylase activity along with higher TSS and lower starch content in synthetics indicated a heat efficient amylase and starch metabolising pathway. In literature, various epigenetic and genetic changes occurring at the genome level during the formation of SHWs have been reported to cause the superiority of different SHWs with similar parents for different traits, which might be a reason the differential expression of the amylase activity in selected SHWs. However, the differential biochemical and gene expression results of amylases in the SHWs and durum parents opens up a future perspective for identifying the novel allelic forms of genes involved in starch metabolism along with various enzymes involved heat stress tolerance.

\section{Declarations}


Acknowledgements: Funding received from Department of Biotechnology, New Delhi, India in the form of project no. BT/IN/IndoUK/CGAT/16/SK/2014-15 is highly acknowledged.

Conflicts of interest/Competing interests: The authors declare that there is no conflict of interest

Ethics approval: NA

Consent to participate: NA

Consent for publication: All the authors have agreed for the publication of this manuscript

Availability of data and material: NA

Code availability: NA

Authors' contributions: SK and KS conceived and designed the research. AK conducted the experiments and collected and analyzed the data. SKG helped in all biochemical analysis work, SaK and SHW helped in the analysis of results SK, MG, PC, SHW and AK produced the final draft of the manuscript. SK, KS and PC reviewed the experiments and manuscript.

\section{References}

1. Grote U, Fasse A, Nguyen TT, Erenstein O (2021) Food security and the dynamics of wheat and maize value chains in Africa and Asia. Front Sustain Food Syst 4:329. https://doi.org/10.3389/FSUFS.2020.617009

2. FAO (2020) FAOSTAT statistical database. [Rome]: FAO, 1997

3. Ortiz R, Sayre KD, Govaerts B, et al (2020) Climate change: Can wheat beat the heat? 126:46-58. https://doi.org/10.1016/j.agee.2008.01.019

4. Al-Ashkar I, Alotaibi M, Refay Y, et al (2020) Selection criteria for high-yielding and early-flowering bread wheat hybrids under heat stress. PLoS One 15:e0236351. https://doi.org/10.1371/journal.pone.0236351

5. Acevedo E, Silva P, Fraga H, et al (1999) Bread wheat, durum wheat, and synthetic hexaploid wheat in saline and non-saline soils. Wheat Special Report No. 49, Mexico, D.F.: CIMMYT

6. Awasthi R, Bhandari K, Nayyar H (2015) Temperature stress and redox homeostasis in agricultural crops. Front Environ Sci 3:1-24. https://doi.org/10.3389/fenvs.2015.00011

7. Asseng S, Martre P, Maiorano A, et al (2019) Climate change impact and adaptation for wheat protein. Glob Chang Biol 25:155-173. https://doi.org/10.1111/gcb.14481

8. Kumar U, Singh RP, Dreisigacker S, et al (2021) Juvenile Heat Tolerance in Wheat for Attaining Higher Grain Yield by Shifting to Early Sowing in October in South Asia. Genes 2021, Vol 12, Page 1808 12:1808. https://doi.org/10.3390/GENES12111808

9. Bhatt R, Kaur R, Ghosh A (2019) Strategies to Practice Climate-Smart Agriculture to Improve the Livelihoods Under the Rice-Wheat Cropping System in South Asia. Sustain Manag Soil Environ 29-71. https://doi.org/10.1007/978-981-13-8832-3_2

10. Cheng W, Sakai H, Yagi K, Hasegawa T (2010) Combined effects of elevated [CO2] and high night temperature on carbon assimilation, nitrogen absorption, and the allocations of $\mathrm{C}$ and $\mathrm{N}$ by rice (Oryza sativa L.). Agric For Meteorol 150:1174-1181. https://doi.org/10.1016/J.AGRFORMET.2010.05.001

11. Gupta NK, Agarwal S, Agarwal VP, et al (2013) Effect of short-term heat stress on growth, physiology and antioxidative defence system in wheat seedlings. Acta Physiol Plant 35:1837-1842. https://doi.org/10.1007/S11738-013-1221-1/TABLES/3

12. Kaur G, Asthir B, Bains NS (2018) Modulation of proline metabolism under drought and salt stress conditions in wheat seedlings. Indian J Biochem Biophys 55:114-124

13. Sairam RK, Srivastava GC, Saxena DC (2000) Increased antioxidant activity under elevated temperatures: A mechanism of heat stress tolerance in wheat genotypes. Biol Plant 43:245-251. https://doi.org/10.1023/A:1002756311146

14. Ritchie S, Swanson SJ, Gilroy S (2000) Physiology of the aleurone layer and starchy endosperm during grain development and early seedling growth: new insights from cell and molecular biology. Seed Sci Res 10:193-212. https://doi.org/10.1017/s0960258500000234

15. Franco OL, Rigden DJ, Melo FR, Grossi-de-Sá MF (2002) Plant a-amylase inhibitors and their interaction with insect a-amylases: Structure, function and potential for crop protection. Eur J Biochem 269:397-412. https://doi.org/10.1046/j.0014-2956.2001.02656.X

16. Deikman J, Jones RL (1985) Control of alpha-amylase mRNA accumulation by gibberellic acid and calcium in barley aleurone layers. Plant Physiol 78:192-198

17. Jacobsen J V., Higgins TJ V. (1982) Characterization of the a-amylases synthesized by aleurone layers of Himalaya barley in response to gibberellic acid. Plant Physiol 70:1647-1653. https://doi.org/10.1104/pp.70.6.1647 
18. Kaur M (2015) Isolation and characterization of alpha-amylase gene during seed germination in wheat (T. aestivum L.). Punjab Agricultural University, Ludhiana

19. Perata P, Matsukura C, Vernieri P, Yamaguchi J (1997) Sugar repression of a gibberellin-dependent signaling pathway in barley embryos. Plant Cell 9:2197-2208. https://doi.org/10.1105/tpc.9.12.2197

20. Sharma P, Sareen S, Saini M (2016) Assessing genetic variation for heat stress tolerance in Indian bread wheat genotypes using morphophysiological traits and molecular markers. Plant Genet Resour Characterisation Util 1-9. https://doi.org/10.1017/S1479262116000241

21. Jafarzadeh J, Bonnett D, Jannink J-L, et al (2016) Breeding value of primary synthetic wheat genotypes for grain yield. PLoS One 11:e0162860. https://doi.org/10.1371/journal.pone.0162860

22. Cossani CM, Reynolds MP (2015) Heat Stress Adaptation in Elite Lines Derived from Synthetic Hexaploid Wheat. Crop Sci 55:2719. https://doi.org/10.2135/cropsci2015.02.0092

23. Elbashir AAE, Gorafi YSA, Tahir ISA, et al (2017) Wheat multiple synthetic derivatives: a new source for heat stress tolerance adaptive traits. Breed Sci 67:248-256. https://doi.org/10.1270/jsbbs.16204

24. Heath RL, Packer L (1968) Photoperoxidation in isolated chloroplasts. I. Kinetics and stoichiometry of fatty acid peroxidation. Arch Biochem Biophys 125:189-198. https://doi.org/10.1016/0003-9861(68)90654-1

25. Alexieva V, Sergiev I, Mapelli S, Karanov E (2001) The effect of drought and ultraviolet radiation on growth and stress markers in pea and wheat. Plant, Cell Environ 24:1337-1344. https://doi.org/10.1046/j.1365-3040.2001.00778.x

26. Blois MS (1958) Antioxidant determinations by the use of a stable free radical. Nature 181:1199-1200. https://doi.org/10.1038/1811199a0

27. Marklund S, Marklund G (1974) Involvement of the superoxide anion radical in the autoxidation of pyrogallol and a convenient assay for superoxide dismutase. Eur J Biochem 47:469-474. https://doi.org/10.1111/j.1432-1033.1974.tb03714.x

28. Marcocci L, Maguire JJ, Droy-Lefaix MT, Packer L (1994) The nitric oxide-scavenging properties of Ginkgo biloba extract EGb 761. Biochem Biophys Res Commun 201:748-755. https://doi.org/10.1006/bbrc.1994.1764

29. Li Y, Jiang B, Zhang T, et al (2008) Antioxidant and free radical-scavenging activities of chickpea protein hydrolysate (CPH). Food Chem 106:444-450. https://doi.org/10.1016/j.foodchem.2007.04.067

30. Swain T, Hillis WE (1959) The phenolic constituents of Prunus domestica I.-The quantitative analysis of phenolic constituents. J Sci Food Agric 10:63-68. https://doi.org/10.1002/JSFA.2740100110

31. Zhishen J, Mengcheng T, Jianming W (1999) The determination of flavonoid contents in mulberry and their scavenging effects on superoxide radicals. Food Chem 64:555-559. https://doi.org/10.1016/S0308-8146(98)00102-2

32. Dubois M, Gilles KA, Hamilton JK, et al (1956) Colorimetric method for determination of sugars and related substances. Anal Chem 28:350356

33. Doehlert DC, Duke SH (1983) Specific determination of a-amylase activity in crude plant extracts containing $\beta$-amylase. Plant Physiol 71:229-234. https://doi.org/10.1104/pp.71.2.229

34. Livak KJ, Schmittgen TD (2001) Analysis of relative gene expression data using real-time quantitative PCR and the 2- $\triangle \triangle C T$ method. Methods 25:402-408. https://doi.org/10.1006/meth.2001.1262

35. Mendiburu F de (2019) Agricolae: Statistical procedures for agricultural research. 1-153

36. Kassambara A, Kassambara MA (2020) Ggpubr: "ggplot2" based publication ready plots

37. Wickham H (2016) GGplot2: Elegant graphics for data analysis. Springer International Publishing, New York

38. Sandhu SS, Kaur P, Gill KK, Vashisth BB (2020) The effect of recent climate shifts on optimal sowing windows for wheat in Punjab, India. J Water Clim Chang 11:1177-1190. https://doi.org/10.2166/wcc.2019.241

39. Malenčić D, Vasić D, Popović M, Dević D (2004) Antioxidant systems in sunflower as affected by oxalic acid. Biol Plant 48:243-247. https://doi.org/10.1023/B:BIOP.0000033451.96311.18

40. Sanghera AK, Thind SK (2016) Evaluation of seedling growth and MDA content of wheat genotypes in relation to heat tolerance. Indian J Sci Technol 9:1-5. https://doi.org/10.17485/ijst/2016/v9i31/50284

41. Chakraborty U, Pradhan B (2012) Oxidative stress in five wheat varieties (Triticum aestivum L.) exposed to water stress and study of their antioxidant enzyme defense system, water stress responsive metabolites and H2O2 accumulation. Braz Soc Plant Physiol 24:117-130

42. Mittler R (2002) Oxidative stress, antioxidants and stress tolerance. Trends Plant Sci 7:405-410. https://doi.org/10.1016/S13601385(02)02312-9

43. Pastori GM, Foyer $\mathrm{CH}$ (2002) Common components, networks, and pathways of cross-tolerance to stress. The central role of "redox" and abscisic acid-mediated controls. Plant Physiol 129:460-468. https://doi.org/10.1104/pp.011021

44. Mittler R, Vanderauwera S, Gollery M, Van Breusegem F (2004) Reactive oxygen gene network of plants. Trends Plant Sci 9:490-498. https://doi.org/10.1016/j.tplants.2004.08.009 
45. Hairat S, Khurana P (2015) Evaluation of Aegilops tauschii and Aegilops speltoides for acquired thermotolerance: Implications in wheat breeding programmes. Plant Physiol Biochem 95:65-74. https://doi.org/10.1016/j.plaphy.2015.07.009

46. Gill SS, Singh LP, Tuteja N, Gill R (2012) Generation and scavenging of reactive oxygen species in plants under stress. Improv Crop Resist to Abiotic Stress 1:49-70. https://doi.org/10.1002/9783527632930.ch3

47. Wahid A, Gelani S, Ashraf M, Foolad MR (2007) Heat tolerance in plants: An overview. Environ Exp Bot 61:199-223. https://doi.org/10.1016/j.envexpbot.2007.05.011

48. Savicka M (2010) Effects of high temperature on malondialdehyde content, superoxide production and growth changes in wheat seedlings (Triticum aestivum L.). Ekologija 56:26-33. https://doi.org/10.2478/v10055-010-0004-x

49. Sharma S, Mor V, Singh V, Yashveer S (2019) Effect of elevated temperature on speed of germination in Wheat (Triticum spp .). In: Golden Jubilee International Salinity Conference. p 216

50. Rascio A, Picchi V, Naldi JP, et al (2015) Effects of temperature increase, through spring sowing, on antioxidant power and health-beneficial substances of old and new wheat varieties. J Cereal Sci 61:111-118. https://doi.org/10.1016/j.jcs.2014.09.010

\section{Figures}

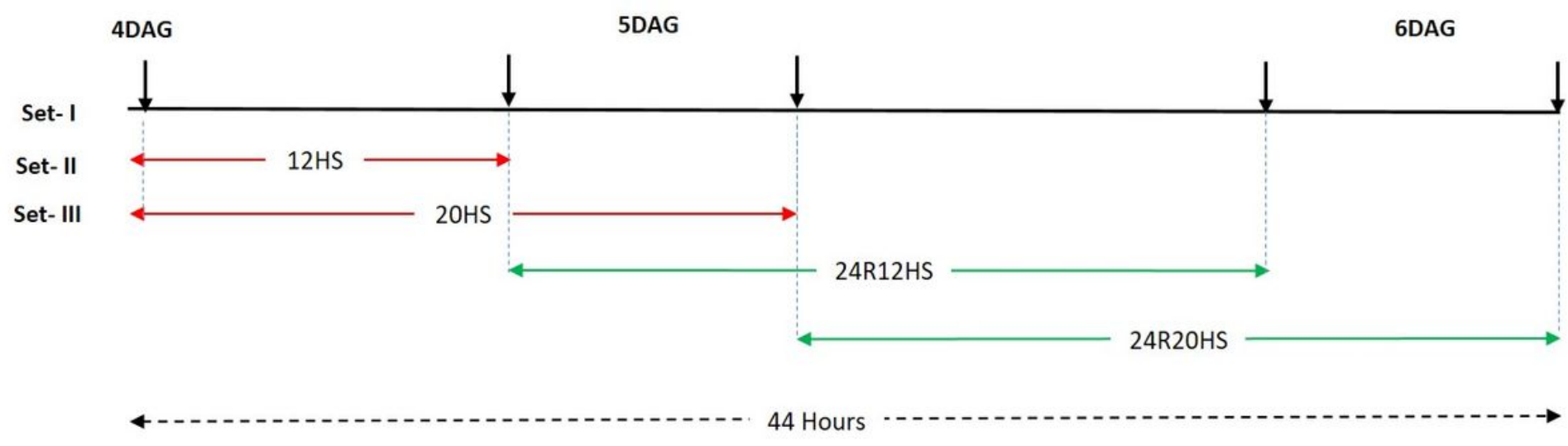

\section{Figure 1}

Experimental setup for the study. Set I maintained at $25^{\circ} \mathrm{C} / 17^{\circ} \mathrm{C}(16 \mathrm{hr}$ light/ $8 \mathrm{hr}$ dark $) 4$ days after germination and treated as control. Set II and set III shifted to $45^{\circ} \mathrm{C}$ (16hr light/ $8 \mathrm{hr}$ dark) for 12 hours and 20 hours, respectively for exposure to heat stress and again moved to $25^{\circ} \mathrm{C} / 17^{\circ} \mathrm{C}$ (16hr light/ 8hr dark) for a 24-hour recovery period after heat stress. 


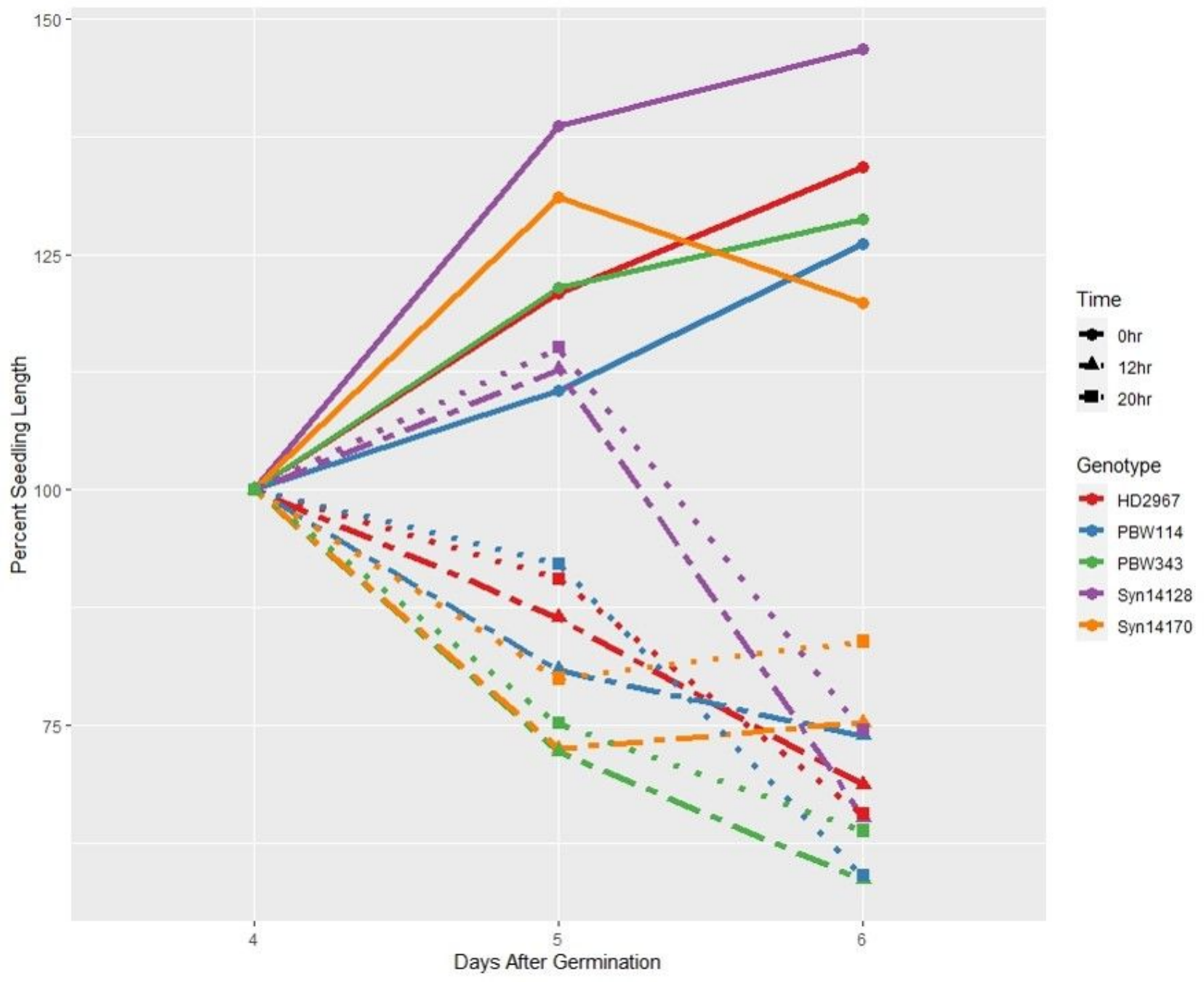

Figure 2

Percent change in the seedling length in different wheat genotypes under control, heat shock (12hr- and 20hr-) and recovery period. 


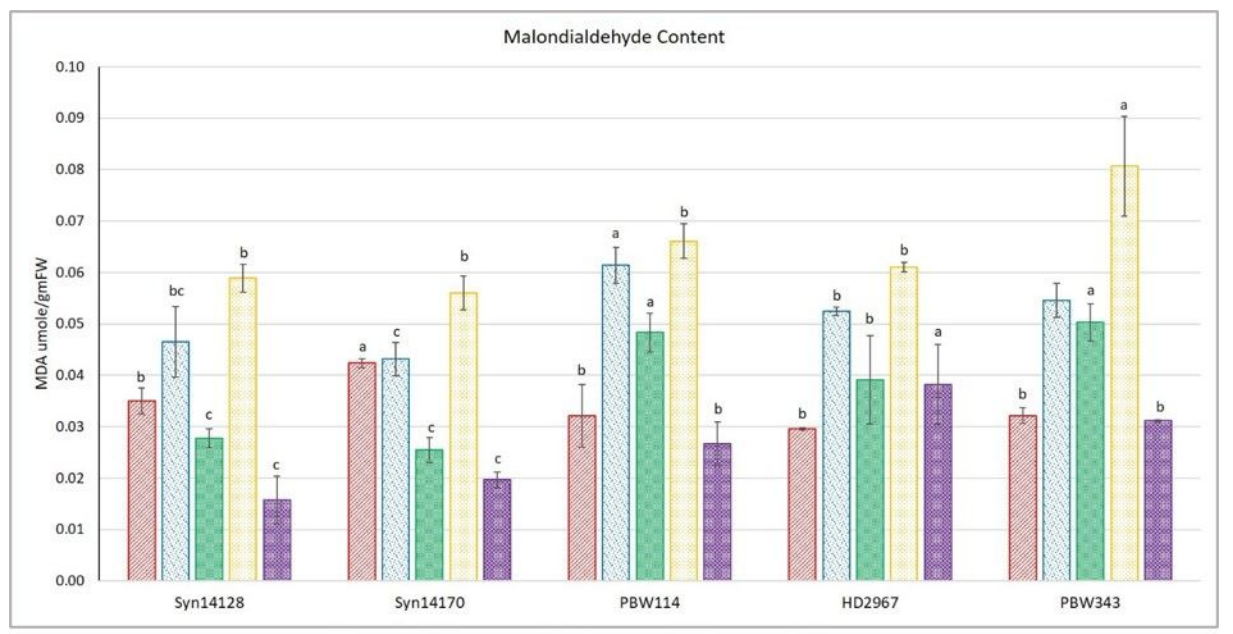

(a)

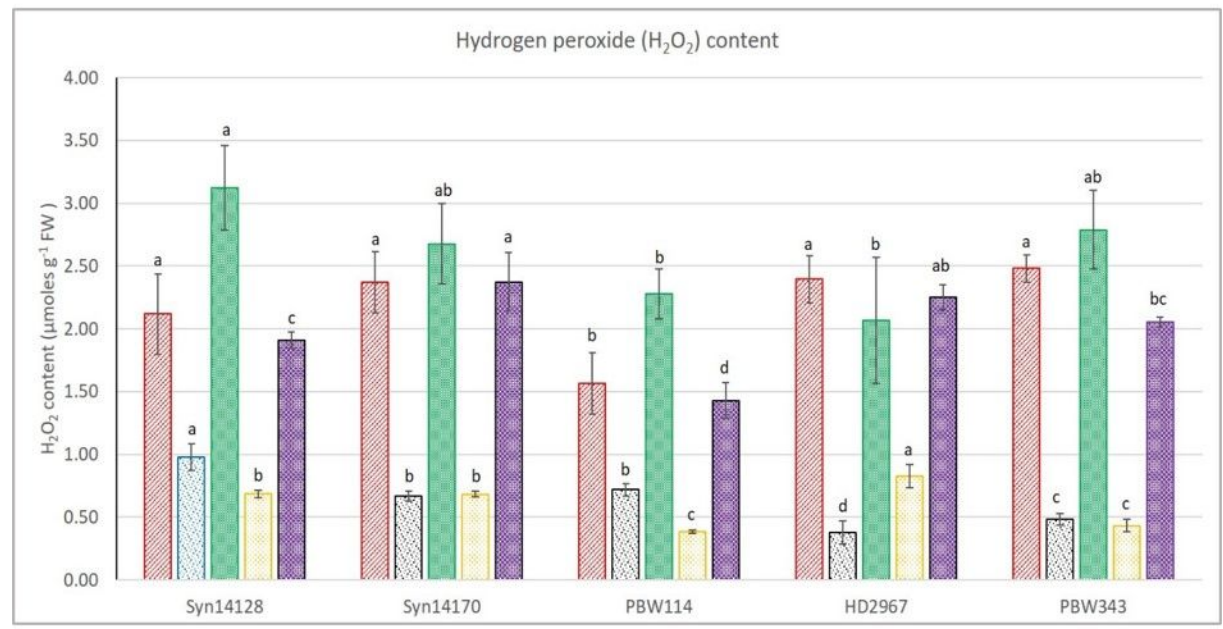

(b)

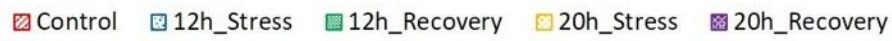

Figure 3

Malondialdehyde content (a) and $\mathrm{H}_{2} \mathrm{O}_{2}$ content (b) in wheat seedlings under control, heat stress and recovery period. Error bars represent the standard deviation of three replicates. The different alphabetical letters in superscript indicate the significant differences with the Duncan test at p-value 0.05 . 


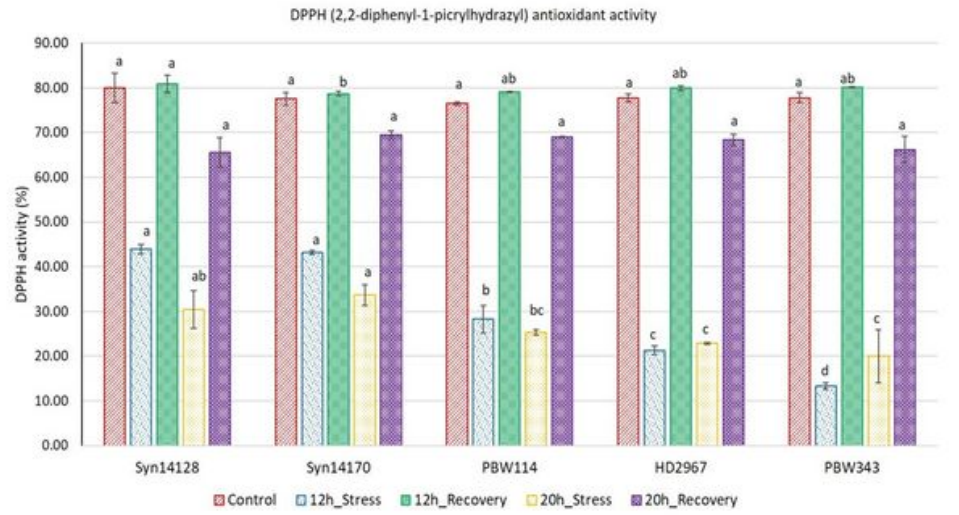

(a)

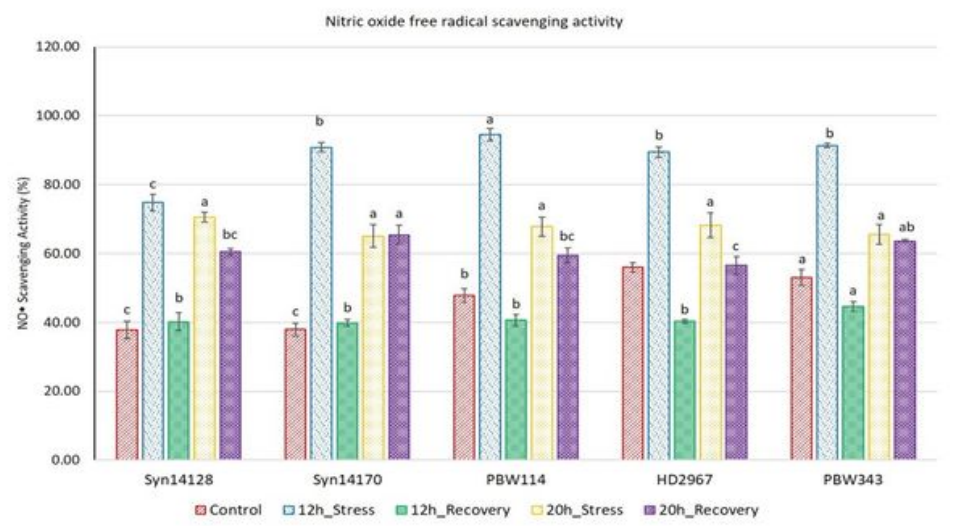

(c)

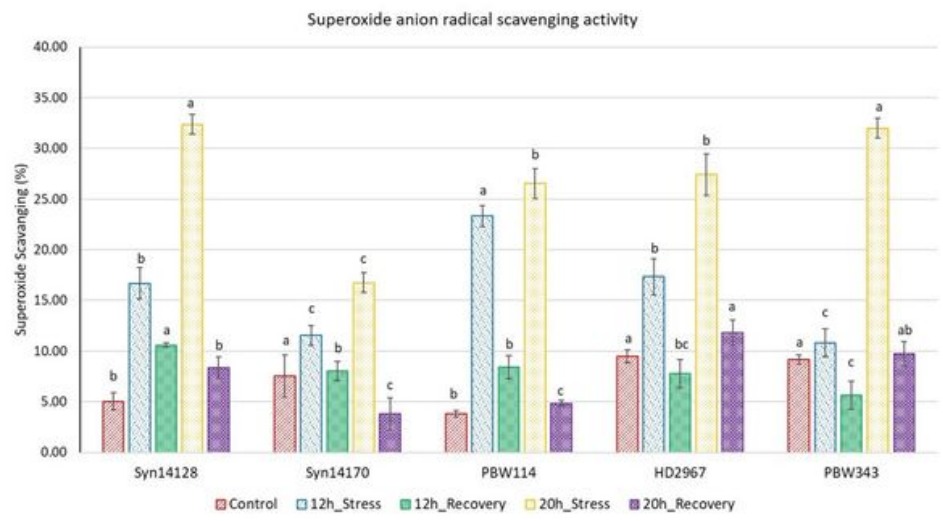

(b)

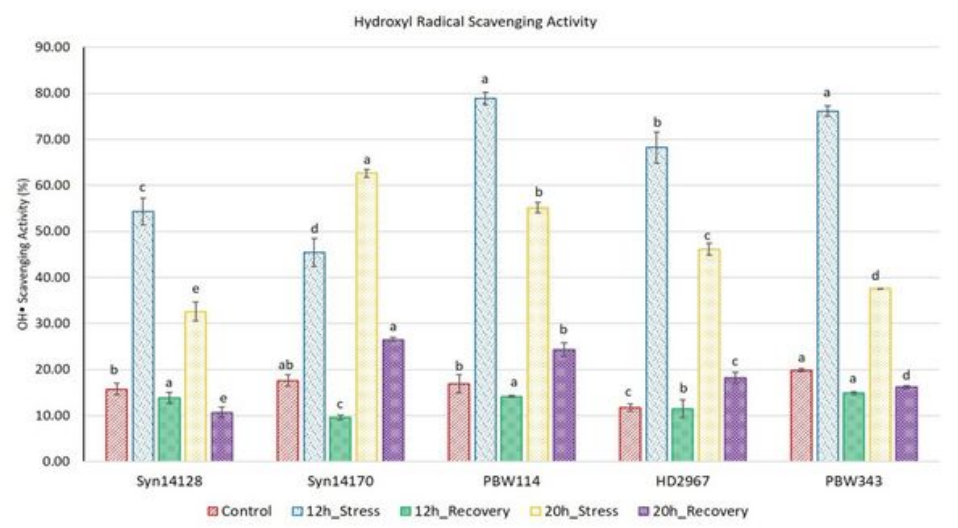

(d)

Figure 4

$\operatorname{DPPH}(a)$, superoxide anion free radical (b), nitric oxide free radical (c) and hydroxyl anion free radical (d) scavenging activities in control, heat stress (12hr- and 20hr-) and recovery period. Error bars represent the standard deviation of three replicates. The different alphabetical letters in superscript indicate the significant differences with the Duncan test at p-value 0.05 . 


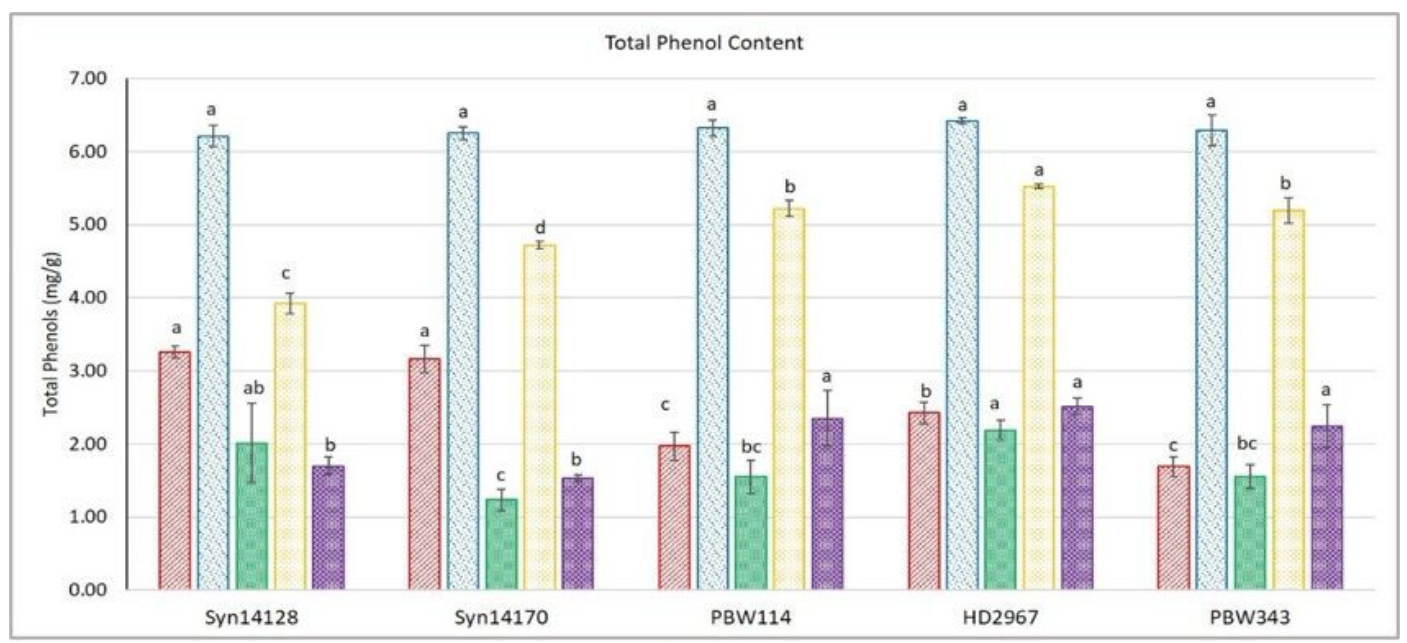

(a)

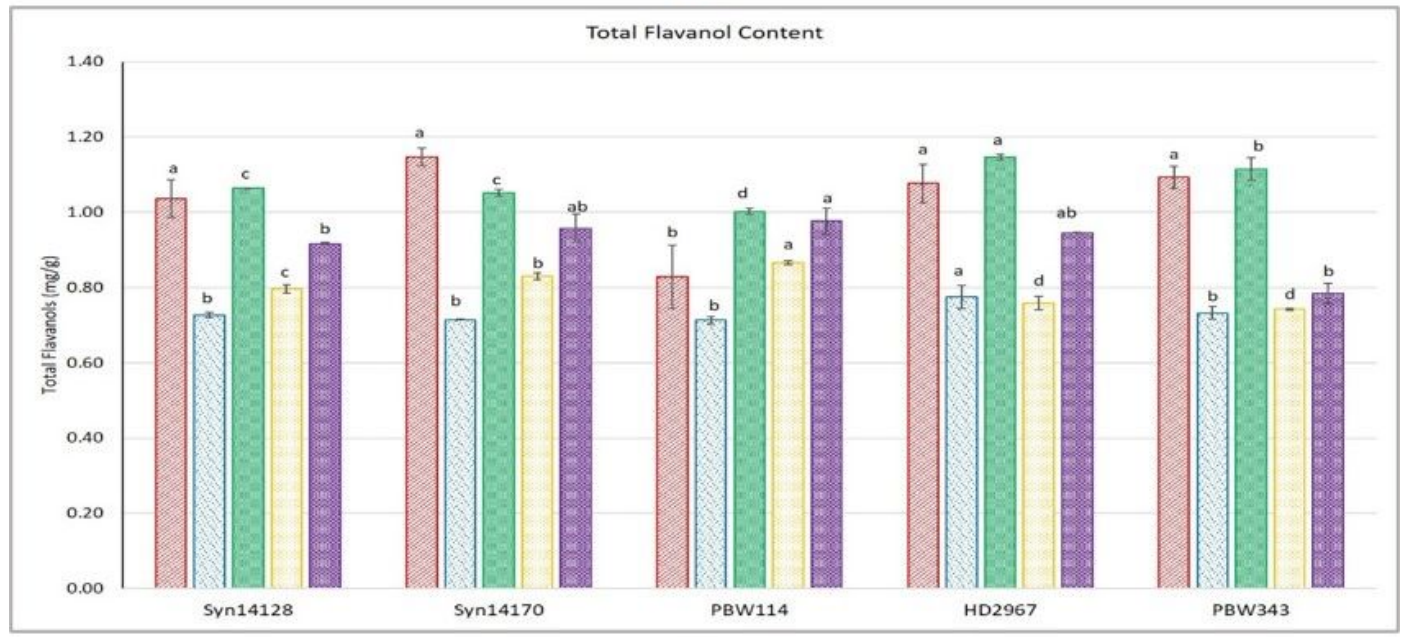

(b)

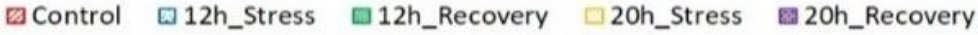

Figure 5

Content and per cent change in total phenols (a) and total flavanols contents (b) in control, heat stress (12hr- and $20 \mathrm{hr}-)$ and recovery period. Error bars represent the standard deviation of three replicates. The different alphabetical letters in superscript indicate the significant differences with the Duncan test at p-value 0.05 . 

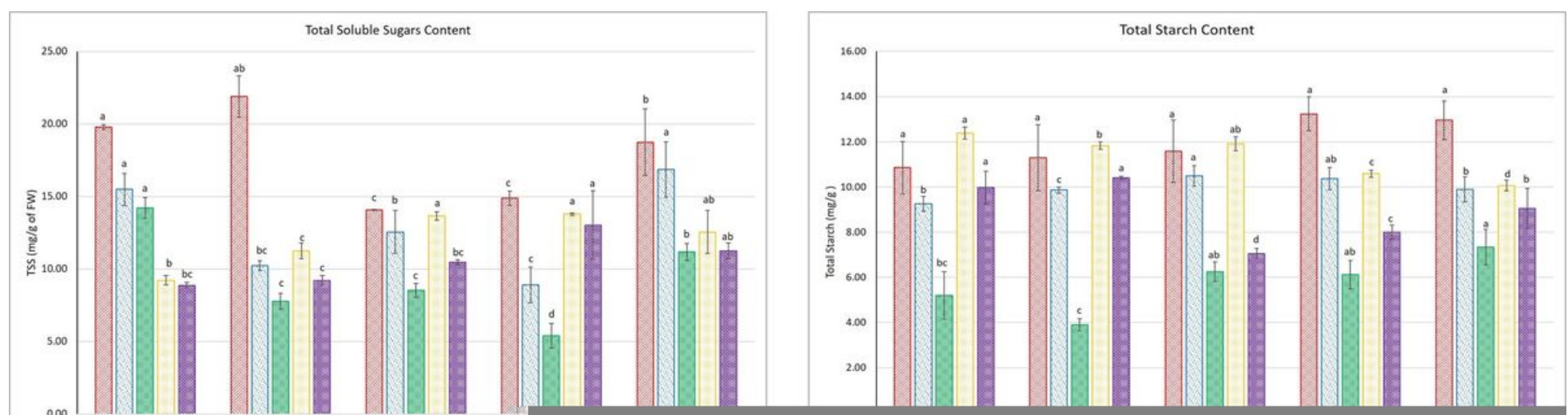

\section{Figure 6}

Content and per cent change in total soluble sugar content (a), starch content (b), amylase activity (c) along with the gene expression (d) of aamylase, amy4, in control, heat stress (12hr- and $20 \mathrm{hr}-)$ and recovery period. Error bars represent the standard deviation of three replicates. The different alphabetical letters in superscript indicate the significant differences with the Duncan test at p-value 0.05 .

\section{Supplementary Files}

This is a list of supplementary files associated with this preprint. Click to download.

- SupplementaryFig.docx

- SupplementaryTables.docx 